\title{
A Critical Analysis of Legal Aid in Bangladesh
}

\author{
Md. Nannu Mian (Corresponding author) \\ LL.B. (Hons.), LL.M. (SEU), PhD-Candidate (IIUM) \\ Assistant Professor, Department of Law, Uttara University \\ House: 1, Road: 12, Sector: 6, Uttara, Dhaka-1230, Bangladesh \\ Email:nannu_1lb@yahoo.com; nannumian@hotmail.com
}

Md. Mamunur Rashid

LL.B. (Hons.), LLM (RU)

Lecturer, Department of Law, Uttara University, Dhaka, Bangladesh

Received: August 20, 2013 Accepted: December 17, 2013 Published: March 11, 2014

doi:10.5296/ijssr.v2i1.5268 URL: http://dx.doi.org/10.5296/ijssr.v2i1.5268

\begin{abstract}
Legal aid is essentially a mechanism that enables the poor and the vulnerable sectors of the society to be able to enforce their legal rights in order to access a fair and equitable justice in the society. Nowadays, a legal aid can be justifiably said as a crying need to ensure social and legal justice in Bangladesh because most of the citizens are illiterate and they live below the poverty line which incidentally makes matters worse. Due to their financial crisis or lack of legal knowledge they are often precluded to access justice. In recognizing the legal aid as a right, the government has enacted some laws. However, unfortunately those laws are full of weaknesses, loopholes, and procedural complexities which have to be judiciously addressed in the proper legal perspectives. As a matter of fact, legally speaking, much has been said and done, but ironically not much has been practiced. Due to these ever unsettling defects, the ultimate objectives of those laws have frequently failed to ensure enjoyment of the legal aid services among the vulnerable sectors of the society. In this research, an attempt has been made to analyze and find out numerous legal the gaps, loopholes and complexities of the existing laws relating to legal aid services in Bangladesh and frame out a comprehensive solution for ensuring the aid program by adopting the qualitative and the analytical research methods.
\end{abstract}


Keywords: legal aid, poor litigant, government, statutory laws, Bangladesh

\section{Introduction}

In a democratic country, it is an immitigable prerequisite that all citizens get economic and social justice in one way or another. Therefore, as long as the poor exists in the society, a legal aid will be necessary to uphold human rights and equality for one and all. Realizing the importance of a legal aid in a given social atmosphere, the developed countries like, UK, the USA and Canada have adopted the legal aid program. ${ }^{i}$ In these developed countries legal aid has been identified as an effective instrument for erasing the socio-economic disparities in their societies. It is for this reason that the benefit of a legal aid has been extended to the deserving members of the society not as a charity but as their civil right with the Constitutional backing and support. Legal aid is an instrument to achieve a visible protection in the law as it is well established and embedded in the Constitution of Bangladesh. ${ }^{\text {ii }}$

Governments of all states irrespective of their standing in the international communities are now increasingly more concerned on the welfare of their citizens. In this regard, the issue of a legal aid is also very important from the political perspective. The third paragraph of the Constitution of the People's Republic of Bangladesh states that - it shall be a fundamental aim of the State to realize through the democratic process to socialist society, free from exploitation, a society in which the rule of law, fundamental human rights and freedom, equality and justice, political, economic and social, will be secured for all citizens without undue restraints. Hence, it is clear from the above paragraph that the Government of Bangladesh has to vehemently set a target to develop a socialist society which will be free from exploitation wherein the rule of law, fundamental human rights and freedom, equality and justice, political, economic and social, will be secured for all citizens without partiality and prejudice. ${ }^{\text {iii }}$

It is one of the principles of Natural Justice that nobody should be condemned unheard. That is, before condemning a person, the judge must hear the person, if he has anything to say to prevent the miscarriage of justice. Again, article 27 of the Bangladesh Constitution provides that all citizens are equal before the law and are entitled to have an equal protection of the law. In the case of Dr. Neelima Ibrahim vs. Bangladesh, ${ }^{i v}$ it was held that the principle of audi alterem partem (hear the other party) unless expressly excluded by law or by the nature of the objects of any particular law is to be implied to have been proved in every statute. But the fact is that due to financial constraints and social inequality not all are equally privileged to get the benefits of the law. Thus, jurisprudential concepts of 'equality before the law', 'equal protection of the law', 'rule of law' have been provided in the past as the rationale for legal aid movement."

\section{Definition of Legal Aid}

A legal aid, in the truest sense of the words, connotes the assistance provided to weaker sectors of the society in the protection of their rights and entitlements under the law and constitution. $^{\text {vi }}$ The New Encyclopedia Britannica defines a legal aid as the professional legal assistance given, either free or for a nominal sum, to indigent persons in need of such helps. ${ }^{\text {vi }}$ 
According to the Legal Aid Services Act, 2000 Legal aid connotes the assistance in terms of legal advice, lawyers' fees, litigation costs and other incidental expenses, provided to the economically disadvantaged populations including those who, for various socio-economic considerations, are unable to access justice. ${ }^{\text {viii }}$

The International Commission of Jurists, in the definition of the term, includes the provisions of legal advice and representation in the courts to all those threatened as to their life, liberty, property or reputation and, by virtue of a certain incidental fact, are unable to pay for it. Legal professionals use the phrase 'legal aid' to mean any or more of the following three issues:

(a) Providing monetary aid; or

(b) Counseling on any legal issue; or

(c) Defending a person in a Court of law. ${ }^{\mathrm{ix}}$

\section{Legal Aid Provisions in Existing Bangladeshi Laws}

The Constitution of Bangladesh itself ensures the basis of the legal aid mechanism by its different articles though there is no explicit and unambiguous expression in any articles on the subject matter concerned. Firstly article 27 says that all the citizens are equal before the law and are entitled to an equal protection of the law. ${ }^{\mathrm{x}}$ Article 14 states that it shall be the fundamental responsibility of the state to emancipate backward sectors of the society from all forms of exploitations. Article 18 says that the state shall endeavor to ensure equality of opportunity to all citizens. Article 31(2) guarantees the protection of law and to be treated only in accordance with the law. Article 35(3) ensures a speedy and fair trial. Article 33(1) states that any person arrested shall not be denied the right to consult and be defended by a legal practitioner of his choice. The Constitution of Bangladesh recognizes the concepts 'equality before the law', 'equal protection of the law', 'rule of law' and other legal concepts wherein the issue 'legal aid' is observed to be underpowered and basically remains as a non-applicable concept. We get the flavor of legal aid in specific provisions in very limited scale in Bangladeshi Laws both in the civil and the criminal sectors. ${ }^{\mathrm{xi}}$

\subsection{Legal Aid in Civil Suits}

As regards civil matters, Order XXXIII of the Code of Civil Procedure, 1908 (CPC) deals with the 'pauper' suit. The Conscious Law Dictionary says that a pauper, is a poor person especially one so indigent as to depend on charity for maintenance or one supported by some public provisions; one so poor that he must be supported at the public expense. ${ }^{\text {xii }}$ The words 'pauper' and 'poor' have nearly the same meaning and they both embrace and connotate several classes. But Explanation to rule 1 of Order XXXIII of CPC provides that a person is a "Pauper" when he does not possess sufficient means to enable him to pay the fee prescribed by law for the plaint in such suit, or where no such fee is prescribed, when he is not entitled to a property worth five thousand taka other than his necessary wearing-apparel and the subject-matter of the suit. ${ }^{\text {iii }}$ 


\subsection{Legal Aid in Criminal Cases}

The need for a legal aid is felt more in criminal matters as the life; property and personal liberty of a person are inseparably connected therewith. As regards criminal matters, section 340 of the Code of Criminal Procedure, 1898 (CrPC) states that an accused should be defended by a lawyer and he must pay the legal fees and nothing more. Commenting on section 340 (1) of the CrPC, the Supreme Court of India observed that the right conferred by section 340 (1) does not extend to a right of an accused person to be provided with a lawyer by the State, or by the police or by the Magistrate. That is a privilege given to him and it is his duty to ask for a lawyer if he wants to engage one and to engage one himself or get his relations to engage one for him. The only duty empowered on the Magistrate is to afford him the necessary opportunity. ${ }^{\text {xiv }}$ In the case of Clarence Earl Gideon vs. Wainwrght, ${ }^{x v}$ the USA Supreme Court has recognized that it is the right of an undefended accused to have a lawyer at the cost of the state. In all criminal prosecutions, the accused shall enjoy the right to have the assistance of a counsel for his defense. The leading case on sixth amendment to the USA Constitution provides that as to the right of a counsel, the courts have "no power and authority to deprive an accused of his life or liberty unless he has or waived the assistance of a counsel. ${ }^{\text {xvi }}$ In death reference cases, a state defense is accorded to the accused by the Legal Remembrance Manual 1960. Legal aid is also provided to the victims of acid violence under the Acid Control Act, 2000. ${ }^{\text {xvii }}$

\subsection{The Legal Aid Services Act, 2000}

The most recent development and operating legislation relating to provide a legal aid in Bangladesh is the Legal Aid Services Act, 2000. According to this Act, the whole legal aid service to indigenous people is conducted through a National Legal Aid Services Board and by its district committees. All the powers and authorities in this regulation of legal aid are vested to the National Legal Aid Board. National Board shall determine the eligibility of the applicants for the legal aid and enact the rules of business in this regard. Different legal aid schemes shall be developed and complemented by legal education and research. The Act envisages initiatives to the Board to make the local people aware of their legal rights through publications, seminars and the media. ${ }^{\text {xviii }}$

\subsubsection{Who Can Apply for Legal Aid}

In the Act, there is no reference as to the eligibility criteria to get a legal aid. Subsequently, the Ministry of Law, Justice and Parliamentary Affairs formulated guidelines and rules under section 24 of the Act to carry out the objectives of the Act. The guidelines enumerate the following categories of persons as eligible for seeking the legal aid: ${ }^{\text {xix }}$

a. Freedom fighter who is incapable of earning or partially incapable of earning or who is without any employment or whose annual income is below six thousand taka;

b. The person who is receiving old age honorarium;

c. Poor women who are holders of VGF Cards;

d. Women and children who are victims of human trafficking activities; 
e. Women and children who are acid-burnt by the miscreants;

f. Any person who has been allocated land or house in a village; poor widow, women deserted by her husband;

g. Physically or mentally handicapped person who is incapable of earning and without means of subsistence;

h. Person who is unable to establish his/her right to defend him/her in a Court of law due to financial crisis;

i. Any other person who is considered eligible by the Legal Aid Board from time to time due to the financial crisis or any other socio-economic reasons or disaster. ${ }^{\mathrm{xx}}$

\subsubsection{How to Apply for Legal Aid}

All applications for getting the legal aids must be submitted to the National Board of Legal Aid or in appropriate cases to the District Legal Aid Committee. If an application is rejected by the District Committee and the person feels aggrieved by that decision, then the applicant may prefer an appeal to the National Legal Aid Board within 60 days of the pronouncement of the decision of the District Committee. ${ }^{\mathrm{xxi}}$ Apart from the aforesaid provisions, the Legal Aid Rules, 2001 provides for the following provisions on how to make an application for a legal aid:

a. The candidate shall apply, along with his full name \& address and the underlying causes for his application, in a white paper.

b. If the application is made for legal aid for any matter in the Supreme Court, it is to be submitted to the Chairman of the organization, on the other hand, if it is for legal aid in any contract, it is to be made to the chairman of the District Committee.

c. The application accepted by the committee is considered in its next meeting.

d. If it is not possible for the committee to make a decision based on the submitted information then the committee may request for further information.

e. Once any application considered to have been accepted, the applicant litigant shall be informed in the prescribed manner. ${ }^{\text {xxii }}$

\subsubsection{Administration of Legal Aid in Bangladesh}

The Aingoto Sohqyota Prodan Ain ${ }^{x x i i i}$ comprehensively provides for the decentralization of activities in the national and the district level. At the national level, there is a National Legal Aid Board, at the district level, there are District Legal Aid Committees, in the Upazilla or Thana level there are the Upazilla Legal Aid Committees and at the Union level, there are provisions for the Union Legal Aid Committees. ${ }^{\text {xiv }}$

\subsubsection{National Legal Aid Board}

At the national level, the whole legal aid scheme is controlled by the National Legal Aid Board (National Board) which is a statutory body whose head office is situated in Dhaka. ${ }^{\mathrm{xx}}$ 


\section{Macrothink}

The Board is managed and administered by a Board of Governors who is constituted by the following persons:

a. The minister of the Ministry of Law, Justice and Parliamentary Affairs who will also be the Chairman of the Board of Governors.

b. Two members of parliament one of whom is from the Govt. ruling party and the other is from the opposite party in the parliament, both of whom will be nominated by the Speaker of the Jatya Sangshad.

c. The Attorney General for Bangladesh.

d. The Secretary of the Ministry of Law, Justice Parliamentary Affairs.

e. The Secretary of the Ministry of Home Affairs.

f. The Secretary of the Ministry of Social Welfare.

g. The Inspector General of Police.

h. The Inspector General of jail.

i. The Vice-Chairman of Bangladesh Bar Council.

j. The President of the Supreme Court Bar Association.

k. The Chairman of the National Women Organization.

1. Representatives of three NGOs, dealing with the Law and Human Rights nominated by the Govt. and who have contributed in different districts.

m. Representatives of three women organizations nominated by the Govt. and who have contributed in different districts.

n. Director, who will be the Secretary of this Board. ${ }^{\text {xxvi }}$

\subsubsection{Functions of the National Board}

The Act lays down an institutional framework for administering a legal aid at national and district levels. According to section 7 of the Act, the National Legal Aid Board will mainly act as a policy-making authority and will discharge the following functions: ${ }^{\mathrm{xxvii}}$

(a) Formulate rules and policies to select a person and to provide legal aids to the people who are unable to get justice due to financial crisis or due to different socio-economic reasons.

(b) Frame the scheme to provide a legal aid.

(c) Take an initiative to organize research and educational activities to provide a legal aid;

(d) Telecast different programs in order to create an awareness among general people on the availability of legal aids in different printed and electronic media. 
(e) Review the application rejected by the District Committee (monitor the activities of the District Committee).

(f) Publish different books, leaflets, pamphlets, etc., for making people aware of getting the legal aid. ${ }^{\text {xxvii }}$

\subsubsection{Meeting of the Board of Governors}

The Act provides for the procedure to be followed while convening a meeting of the Board of Governors of the National Legal Aid Board. ${ }^{\text {xxix }}$ The Chairman of the Board of Governors shall call the meeting at any place at any time in every three months. The Chairman will be the Chairman of all the meetings and in his absence anybody appointed by him shall perform his duties. One-third of the total number of the members will constitute the quorum of the meeting. But for any adjourned meeting no quorum will be required. In such meetings all members will have a single vote.

\subsubsection{District Legal Aid Committee}

The District Legal Aid Committee (District Committee) is solely responsible to provide legal aids at grass root level subject to the availability of funds from the government. The committee shall invite application from the seekers of legal aid, screen the applications, determine the criteria for proviso of legal aid and finally provide the legal aids. The District Legal Aid Committee is constituted by:

a. The District Judge who he will be the Chairman and also

b. The District Magistrate

c. The Superintendent of Police of the District

d. The Jail Superintendent of the District

e. The Social Welfare Officer of the District, if any

f. The Women and Children Officer of the District, if any

g. The Chairman of the National Women Organization or his nominee

h. The President of District Bar Association

i. The Govt. Pleader of the District

j. The District Public Prosecutor

k. The Inspector of the District Civil Jail

1. One representative of the NGO nominated by the District Women Association.

m. The General Secretary of the District Bar Association, who will also be the membersecretary of the organization. 
n. The Metropolitan Magistrate and the Metropolitan Police Superintendent will also be the members of the District Legal Aid Committee where there is a metropolitan city district. $^{\mathrm{xxx}}$

\subsubsection{Duties and Responsibilities of the District Committee}

The District Legal Aid Committee is responsible to perform the following duties:

a. To provide legal aid to the people who satisfy the criteria as set up by the Board of Governors and who are unable to get justice due to financial crisis or due to different socio economic reasons

b. To set up the conditions on which a successful applicant will get the legal aid

c. To take initiative to make the people aware of availability of legal aid

d. To perform the duty invested by the Board and

e. Any other activities necessary for the performance of the above mentioned activities. $^{\text {xxxi }}$

\subsubsection{The Meeting of the District Committee}

The Act provides for the procedure to be followed while convening a meeting of the District Legal Aid Committee. ${ }^{\text {xxii }}$ The Chairman of the District Committee, i.e., the District Judge shall call the meeting at any place at any time every month. The District Judge will be the Chairman of all the meetings and in his absence, anybody appointed by him shall be the chairman. One-third of the total number of the members will constitute the quorum of the meeting. But for any adjournment meeting no quorum will be required. ${ }^{\text {xxxiii }}$

\section{Weaknesses of Legal Aid Act}

Though the Legal Aid Services Act, 2000 is a landmark to the legal empowerment of the disadvantages and vulnerable people, it is not free from criticisms. The Act is full of loopholes and weakness in the whole mechanism of legal aid services. On a careful analysis of the Legal Aid Services Act, 2000 the following loopholes are worth mentioning:

a. The Act does not specify cases for which legal aid can be provided.

b. The process of consideration of application can be identified as another source of delay in meeting the ends of justice as the members of the Board and Committee who will consider the applications are often very busy. As a result the applicant does not get justice when really needed.

c. In comparison with the number of legal aid seekers, the number of meetings held to consider these applications fall short of the requirement, as the Board holds at least one meeting in every three months and the Committee holds one meeting in every month.

d. The accountability of the members of the Board and Committee are not ensured in the Act and for this reason, this Act may meet the same fate as other Acts of Bangladesh. 
It will be treated as a mere ambitious work of the government and this Act will help the Government to speak up in national and international seminars but the fate of the poor people will remain largely unchanged.

e. The procedure of the selection of the application is not clear in this Act, i.e., the basis of consideration, the criteria for selection and above all the requisite number of members to give consent to such granting of application is not clear.

f. The members of the committees being from the upper strata of society, they often fail to realize the depth of miseries of these persons and cannot acquaint themselves with their problems.

g. In the Upazilla and Union committees, the inclusion of Chairman and 14 other members makes the system more complex as it will be seen in most of the cases the legal aid seekers are the victim of the activities of these people.

h. Though the Act has emphasized to sensitize local people on the legal aid scheme by publications, seminars and media, the services are not implemented due to lack of publicity to a great extent.

i. The whole procedure to get legal aid under this Act is full of difficulties due to its highly bureaucratic system.

j. The whole attempt to establish the National Legal Aid Services and facilities in the country can be aptly considered and stated as an Exercise in Futility as long as there is no time frame fixed and pragmatic solutions found for the coordination of operation and application of the legal aid services.

\section{Recommendations}

The Legal Aid Service mechanism run by the existing laws of Bangladesh would be great success if the following measures are taken by the government:

(i) The National Legal Aid Service head office should be reasonably equipped with a logistic capacity including manpower for monitoring and coordinating network that operates all over the country.

(ii) The District Legal Aid office should be located in the same premises of the District and Session Judge Court so that the aid seekers can communicate without difficulty.

(iii) Regular meeting of the National Legal Aid Service committee and District committee should be strictly ensured and monitored.

(iv) Awareness building regarding government legal aid service should be extended over the country through various ways such as print media, electronic media, seminars and symposiums.

(v) The annual reports prepared by the Distinct Legal Aid committee submitting to the head office of the board should be regular, consistent and to be followed a format recommended to be developed by the National Legal Aid Board. 


\section{Conclusion}

Equality before the law, equal protection of the law and rule of law which are all guaranteed by the constitution of the Republic will cease to be effective if the poor and vulnerable sectors of the populace are not properly provided with a legal aid facility or legal aid mechanism which has to be properly implemented. It is better to do something imperfectly rather than to do nothing flawlessly. A good plan implemented today is better than a perfect plan left for tomorrow. Hence, the government should develop an atmosphere which should be more conducive to address the loopholes of the legal aid service mechanism and to take concerted efforts with the NGOs to provide a smooth legal aid for ensuring access to justice among the poor litigants. It is not too misleading if we were to say that ideas without action are worthless. Vision without action is just a daydream. Action without vision is a nightmare.

\section{References}

Akhtaruzzaman, M. (2013). Concept and Laws on Alternative Dispute Resolution and Legal Aid. Dhaka: Advocate Razia Khatun.

Ali, T. (2007). BRAC's legal aid program and justice seeking behaviour. Dhaka: BRAC. BRAC Research report unpublished.

Bangladesh Legal Aid and Services Trust (BLAST). (2005a). Annual report 2004-2005. Dhaka: Bangladesh Legal Aid and Services Trust (BLAST).

Bangladesh Legal Aid and Services Trust (BLAST). (2005b). Gender, knowledge, networking and human rights intervention in Bangladesh (GKNHRIB): Concept note on extension of GKNHRIB, BLAST. Dhaka: Bangladesh Legal Aid and Services Trust (BLAST).

Bangladesh Legal Aid and Services Trust (BLAST). (2005c). Public interest litigation and advocacy, BLAST: Impact Study 2005. Dhaka: Bangladesh Legal Aid and Services Trust (BLAST).

Bangladesh Legal Aid and Services Trust (BLAST) (2006). Strategic policy and future direction of BLAST. Dhaka: Bangladesh Legal Aid and Services Trust (BLAST).

Halim, A., \& Siddiki, N. E. (2008). The Legal System of Bangladesh: After Separation. Dhaka: Shams Publication.

Haque, K. E. (2003). Administration of Justice in Bangladesh. Dhaka: Asiatic Society of Bangladesh.

Iyer, V. R. (1993). Access to Justice. Delhi: B.R. Publishing Corporation.

Khair, S. (2000). Alternative Dispute Resolution: How to works in Bangladesh. Dhaka University Studies, Part F, Dhaka.

Khair, S. (2006). Legal Empowerment of Women and Disadvantaged Group. Country Situation Analysis Report, Dhaka: The Asian Foundation. 
Khan, A. A. (2010). An Introduction to Alternative Dispute Resolution (ADR) and Legal Aid. Dhaka: Hira Publication.

Madaripur Legal Aid Association (MLAA). (2005). Annual report 2004-2005. Dhaka: MLAA.

The Legal Aid Service Act. (2000).

\section{Notes}

i Abdul Halim \& Siddiki, The Legal System of Bangladesh: After Separation. Dhaka: Shams Publication, 2008, pp.7-18.

ii Ibid.

iii Kazi Ekramul Haque, K. E., Administration of Justice in Bangladesh. Dhaka: Asiatic Society of Bangladesh, 2003, pp. 23-29.

iv 32 DLR (1980) 201

v Ibid.

vi Sumaiya Khair, Legal Empowerment for the Poor and the Disadvantaged: Strategies Achievements and Challenges Dhaka, 2008.

vii The New Encyclopedia Britannica, Vol. VI,P.122

viii Section 2(a) of the Legal Aid Services Act, 2000

ix The Legal system in Bangladesh by Abdul Halim and N.E Siddiki, p. 346

${ }^{x}$ Khan, An Introduction to Alternative Dispute Resolution (ADR) and Legal Aid. Dhaka: Hira Publication, 2010, pp. 9-18.

xi Sumaiya Khair, Legal Empowerment of Women and Disadvantaged Group. Country Situation Analysis Report, Dhaka: The Asian Foundation, 2006.

xii Supra, note at 10.

xiii Ibid.

${ }^{\mathrm{xiv}} \mathrm{Ali}$, BRAC's legal aid program and justice seeking behaviour. Dhaka: BRAC. BRAC Research report unpublished, 2007.

xv 372 U.S. 335 (1963)

xvi Supra, note at 5, p. 349

xvii Section 8 of the Acid Control Act, 2000

xviii The Legal Aid Services Act, 2000 
${ }^{x i x}$ Rule 2 of the Legal Aid Service Rule, 2001

${ }^{\mathrm{xx}}$ In this guideline, the phrase "poor and financially poor person" will be used to mean persons whose annual income is not above three thousand taka.

xxi Section 16 of the Legal Aid Service Act, 2000

xxii Rule 3 of the Legal Aid Service Rule, 2001

xxiii Act No. VI of 2000

xxiv Bangladesh Legal Aid and Services Trust (BLAST), Annual report 2004-2005, Dhaka: Bangladesh Legal Aid and Services Trust (BLAST), 2005, pp. 12-19.

${ }^{\mathrm{xxv}}$ Bangladesh Legal Aid and Services Trust (BLAST) (2006). Strategic policy and future direction of BLAST, Dhaka: Bangladesh Legal Aid and Services Trust (BLAST).

${ }^{x x v i}$ Section 6 of the Legal Aid Service Act, 2000

xxvii Section 7 of the Legal Aid Service Act, 2000

xxviii Ibid.

xxix Section 8 of The Legal Aid Services Act, 2000

${ }^{x x x}$ Section 9 of the Legal Aid Service Act, 2000

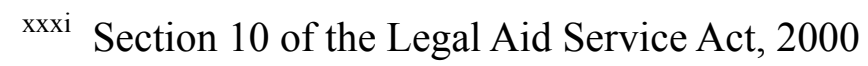

xxxii Section 11 of the Legal Aid Service Act, 2000

xxxiii Ibid.

\section{Copyright Disclaimer}

Copyright reserved by the author(s).

This article is an open-access article distributed under the terms and conditions of the Creative Commons Attribution license (http://creativecommons.org/licenses/by/3.0/). 